\title{
The Goof, The Bad and The Ugly: Indecent Language Use On Ghanaian Radio
}

\author{
Margaret Ivy Amoakohene, Jemima Asabea Anderson, Jemima Opare-Henaku
}

\begin{abstract}
Free speech and media freedoms were reinforced in Ghana with the repeal of the Criminal Libel Law in 2001. As a result, the citizen's voice, which was hitherto muted, has grown louder as Ghanaians feel emboldened to contribute to national discourse in the media (especially local language radio programmes) without fear of the Criminal Libel Law. However, concerns have been raised about indecent language which has become pervasive in the Ghanaian media. This study examined indecent language on radio in Ghana. The study adopted the quantitative approach and analysed content data gathered from selected Ghanaian radio stations from May, 2016 to September, 2016. This was the period just before the 2016 presidential and parliamentary elections in Ghana. The study revealed six types of indecent language on Ghanaian radio and noted that insults and offensive comments ranked the highest, while expressions promoting divisiveness ranked lowest.
\end{abstract}

Keywords: media, indecent language, Ghanaian radio, local language broadcast, politics

\section{Résumé}

La liberté de parole et la liberté des médias ont été renforcées au Ghana avec l'abrogation de la loi sur la diffamation pénale en 2001. En conséquence, la voix des citoyens, qui était jusqu'ici en sourdine s' est accrue, les Ghanéens se sentant enhardis de contribuer aux débats nationaux dans les médias (notamment les émissions de radio en langue locale) sans craindre de devenir la proie de la loi sur la diffamation pénale. Cependant, à la suite de cela, le langage indécent est également devenu omniprésent sur les ondes ghanéennes et est devenu une source de préoccupation pour beaucoup. Cette étude a donc examiné l'utilisation de la langue indécente à la radio au Ghana. L'étude a adopté l'approche quantitative et analysé les données recueillies auprès de stations de radio ghanéennes sélectionnées de mai à septembre 2016. Les résultats de l'étude ont révélé six types de langage indécent à la radio ghanéenne.

Mots-clés : médias, langage indécent, radio ghanéenne, émission en langue locale, politique

\begin{abstract}
https://dx.doi.org/10.4314/contjas.v8i2.4
Margaret Ivy Amoakohene (mamoakohene@ug.edu.gh) is an Associate Professor at the Department of Communication Studies, University of Ghana where she has taught Public Relations, Qualitative Research Methods and Mass Communication since September 1992. She has participated in and presented papers on various aspects of communication, the environment, the media, public relations, politics, governance, and women and gender at many seminars, workshops and conferences, both nationally and internationally. She has held many positions in both the University of Ghana and Ghanaian national life, serving on several boards and committees and actively participating in national discussions and debates. She serves on the Council of the Institute of Public Relations (IPR), Ghana, and previously served as its Honorary Secretary and Vice-President.
\end{abstract}

Jemima Asabea Anderson (janderson@ug.edu.gh) is a Senior Lecturer at the Department of English, University of Ghana, where she teaches courses in Pragmatics, Sociolinguistics, English in Ghana and World Englishes. She is co-editor of Crossing Linguistic Borders in Post-Colonial Anglophone Africa. Some of her articles have appeared in Journal of Pragmatics, Journal of Politeness Research, Sociolinguistics Studies, Legon Journal of the Humanities, Linguistic Atlantica and Journal of African Media Studies. Her research interests include Language and the Media in Ghana, Codification of Ghanaian English, Language and Migration in Ghana, Cross-cultural Pragmatics, Pragmatics of non-native varieties of English, Politeness/Impoliteness in English in Ghana, and Language Choice and language use in specific domains in Ghana.

Jemima Opare-Henaku (jemima2g2@yahoo.ca) is currently the Communication Officer for Civic Response, a leading natural resource and environmental (NRE) governance policy advocacy organisation in Ghana. She holds a master's degree in Communication Studies from the University of Ghana, Legon, with specialization in Multimedia Broadcasting and Advertising. Her research interests include media and language, media ethics, media effects, and digital media. 


\section{Introduction}

Ghana ranks $30^{\text {th }}$ on the 2020 World Press Freedom Index (Reporters Without Borders, 2020), third only to Namibia $\left(23^{\text {rd }}\right)$ and Cape Verde $\left(25^{\text {th }}\right)$ in Africa. Ghanaians, therefore, enjoy press freedom and free speech which encompasses the right to express one's views freely verbally, either in speech or in writing. Article 21(1) of the 1992 Constitution of Ghana states that, "all persons shall have the right to freedom of speech and expression, which shall include freedom of the press and other media." Regardless of the existence of this Article, it is the repeal of the Criminal Libel Law in 2001 which engendered free speech in Ghana, especially in the media. Hitherto, Ghanaians, especially journalists, had to censor themselves to ensure that they did not fall foul of the Criminal Libel Law under which some journalists had suffered prison sentences.

In 1992, just before Ghana entered its current democratic dispensation, the Provisional National Defence Council (PNDC) government repealed its newspaper licensing law, PNDCL 211, and subsequently liberalised the airwaves to allow for media pluralism and private participation in the electronic media (Amoakohene, 2012). These changes were marked by an expanded media environment with a rapid growth of independent radio broadcasting. The figures from the National Communications Authority (NCA) indicate that frequency authorisations were at 575 broadcasting stations in Ghana as at June 2020 out of which 428 are in operation (NCA, 2020).

Apart from strengthening media freedom and pluralism, the repeal of the Criminal Libel Law also ushered Ghanaians into an era of free speech and media involvement, which was previously not experienced in the country. Free speech and media freedom, in turn, have had an impact on radio programming as radio stations have injected some level of dynamism and robustness into their programmes. Most radio stations have adopted an interactive live programming approach. Radio programmes have been structured in such a way as to make room for panel discussions where panellists engage in rigorous discussions and debates on issues live on air. Radio audiences have also been given the opportunity to take part in the discourse via telephone calls, WhatsApp and text messages. Again, audiences are able to utilise social media platforms, most notably Facebook and Twitter, to make contributions to live programmes.

However, as interactions on radio over the years have become animated, they have also grown fierce and acrimonious, especially when the topic of discussion is about politics (Asamoah, Yeboah-Assiamah and Osei-Kojo, 2014; Ofori, 2018). Capitalising on the anonymity granted by radio, some programme hosts, studio guests, interviewees and audiences blatantly abuse free speech on a daily basis on Ghanaian airwaves, using offensive language such as insults and hate speech (Thompson and Anderson, 2018). Indecent language on radio has become a matter of great concern to Ghanaians who view it as offensive; against accepted standards and norms of propriety in society; and an affront to Ghanaian culture. As a result, several opinion pieces have been written by some Ghanaians, admonishing people to refrain from the use of indecent language in the media. One such article posted on an online news portal (Ghanaweb) on June 15, 2018 written by Afua Sarpong Kuman Kumaah, titled Indecent language use in public is anti-Ghanaian culture, advised against the use of indecent language and reminded the media of their watchdog role. The writer also urged the media to protect Ghana's culture against indecent language, which is a cultural malpractice (Sarpong, 2018).

For similar reasons as espoused by Sarpong (2018), the Media Foundation for West Africa (MFWA) started monitoring language use on radio stations across the country in order to name and shame users of indecent language in the media (Laary, 2016). Furthermore, the media themselves try to check the use of indecent language by censoring users of such language on the airwaves through hosts of programmes, who caution against indecent language on air. At other times, hosts urge abusers of decent language to retract and/or apologise for the use of indecent language on air. In circumstances where listeners send messages to be read on air, presenters may decide to skip indecent words in the text or stop reading the entire message. The use of indecent and offensive language in the media is not restricted to Ghana. Numerous classifications of indecent language in the Western and African media exist with some nuances across cultures (see Kaye and Sapolsky, 2009; McCreary, 2014; Fordjour, 2016; Olúmúyìwá, 2016; Gustafson, 2017). Research shows that decorum seems to be gradually eroding from society across the globe as indecent language use in the media becomes more pervasive across continents (Sapolsky, Shafer and Kaye, 2010; Ricke, 2012; Schippers, 2013; McCreary, 2014; Ofcom, 2016). Wildes (2020), for instance, studied the proliferation of indecent and profane content on television and noted that the growth rates of indecency and profanity were far greater in modern 
than in previous eras. In contrast to stereotypical notions that men are more likely to use indecent language than women in media spaces, Schippers' (2013) and Gustafson's (2017) studies of American and British media demonstrated there was no difference in usage, either in frequency or strength, by both genders.

Politics seems to be one of the subjects that evoke a lot of passion and use of indecent language on air, especially in democratic settings where free speech is guaranteed. Generally, misrepresentative exaggeration, name calling, insults, and mockery are types of indecent language often heard during political discourse in the media (Sobieraj and Berry 2011). Several scholars, including Agyekum (2004) and Somerville (2011) agree that the use of indecent language in the media surges even further during election periods when stakes are high, causing tension and sometimes even violence.

In countries like Kenya and Rwanda, Kellow and Steeves (1998) and Ismail and Deane (2008) maintain that the media in these two countries played an active role in the use of indecent language that caused tension, as they promoted hate speech and violence-inciting language. This practice does not seem strange to the Ghanaian media as they sometimes take part in perpetrating verbal indecency, either as perpetrators or as channels (Laary, 2016). The need to sanitize political communication in Ghana has been articulated by Asamoah, Yeboah-Assiamah and Osei-Kojo (2014) and Ofori (2018), who found an extreme use of abusive words in the Ghanaian broadcast media and political campaigns. They recommended that political parties should sanction members who use impolite language in political discourse. Marfo (2013) also recommended that the media should blacklist politicians who use their platforms to verbally assault political opponents.

The effects of indecent language are enormous. Many studies highlight its offensiveness to society (Wildes, 2020; Ofcom, 2016; Sapolsky, Shafer and Kaye, 2010). Agyekum (2004) notes that invectives (which form part of indecent language) can cause psychological pain to the recipient. Indecent language may cause damage to people's reputation and self-esteem; and kindle strife and hatred between individuals and groups in a society. Besides, unnecessary suspicion and unsubstantiated allegations hamper and restrict the atmosphere for doing good business. It is against this backdrop that this study sought to examine the extent of indecent language usage on radio, with the aim of examining the frequency and kinds of indecent language used on selected Ghanaian radio stations; the extent to which the frequency and type of indecent language on Ghanaian radio differ according to gender (female versus male); the extent to which the frequency and type of indecent language on Ghanaian radio differ according to language used (local language versus English language); and, the extent to which the frequency and type of indecent language differ according to type of programme (news versus current affairs shows).

To achieve this, the article sheds light on the theoretical framework underpinning this study. The next section deals with the approach the researchers employed to collect and analyse data. We thereafter present the findings followed by discussions, implications and conclusion.

\section{Framing $\mathrm{Im} /$ Politeness}

This study was undertaken within the framework of the impoliteness theory (Culpeper, 1996) based on Brown and Levinson's (1987) politeness theory. The model defines impoliteness as "the use of strategies that are designed to have $\cdots$ social disruption," (Culpeper, 1996, p. 350). The model identifies two types of impoliteness: inherent impoliteness, and mock impoliteness, also known as banter. Inherent impoliteness refers to acts/utterances which threaten the recipient' s face, irrespective of the context within which they were uttered (Brown and Levinson's politeness theory posits that everyone has a positive and negative face, and a public self-image that they want to maintain. Positive face includes being liked by others while negative face includes being independent [Brown \& Levinson, 1987]). Mock impoliteness, on the other hand, refers to utterances which do not aim at causing offense.

The impoliteness framework identifies five strategies. According to Culpeper (1996), these strategies are the opposites of Brown and Levinson's (1987) theory of politeness strategies. These strategies are: bald on record impoliteness; positive impoliteness; negative impoliteness; sarcasm or mock impoliteness; and withhold politeness. With bald on record impoliteness, the Face Threatening Act (FTA) is produced in a "direct, clear, unambiguous and concise way in circumstances where face is not irrelevant or minimised" (Culpeper, 1996, p. 356). Positive impoliteness makes use of utterances which destroy the recipient' s positive face wants. Culpeper (2005) lists ignoring someone, as well as excluding someone from an activity as examples of positive impoliteness. Negative impoliteness involves the use of utterances which attack the receiver's negative face 
wants. Culpeper (2005) lists scorning, ridiculing, belittling others, as well as being contemptuous as examples of negative impoliteness. With sarcasm or mock impoliteness, the speaker makes use of politeness strategies that are insincere, while withhold politeness resorts to the lack of politeness where otherwise anticipated. An example of this is when someone refuses to thank a gift giver. That would be considered as intentional impoliteness. Culpeper (2005) notes that these strategies usually do not occur singularly, but rather they occur as a blend. Of primary importance to this study are the impoliteness strategies which are mostly adopted by speakers to attack the face of their target recipients during indecent language usage on radio.

\section{Methodology}

This study took a mixed methods approach by making use of both quantitative and qualitative methods. Quantitatively, the study employed content analysis to give numerical description of the data as noted by Wimmer and Dominick (2011). The content analysis method was therefore useful in breaking down text statistically. MFWA, as part of its monitoring activities, had recorded and transcribed radio programmes on Ghanaian radio stations across the country throughout 2016.

The researchers requested for, and analysed data gathered between May and September 2016. This period was selected because it was neither too close to, nor too far from the December 7, 2016 general elections in Ghana, during which political rhetoric became heightened. The researchers analysed a total of 254 contents with instances of indecent language, categorised by the MFWA to determine the frequency of occurrence of each type of indecent language using the impoliteness model. Content analysis was also used to investigate the extent to which the frequency and type of indecent language on Ghanaian radio differed according to gender (male versus female), language type (local versus English language), and programme type (news versus current affairs).

The qualitative method of textual analysis was employed as a complement to the content analysis method, to make educated guesses about the most probable meaning of the text as noted by McKee (2001). Bauer, Bicquelet and Suerdem (2014) define textual analysis as a way of decoding and deconstructing text. According to Bainbridge (2011, p. 224), "It is one of the primary tools media researchers use to understand how meaning is made from media texts." Textual analysis was important for making meaning out of raw text as the researchers employed it to arrive at probable connotative interpretations of the indecent language recorded on Ghanaian radio, for the period under study. Therefore, while content analysis dealt with the denotative meaning of the selected text, textual analysis gave a balance by dealing with the connotative meaning of the indecent language recorded on Ghanaian radio for the period under study.

\section{Number and Kinds of Indecent Language Used on Ghanaian Radio}

The study identified 254 cases of indecent language used on radio during the period under study (May to September, 2016). These fell into six categories: insulting and offensive comments, unsubstantiated allegations, provocative comments, remarks endorsing violence, remarks inciting violence, and expressions or comments promoting divisiveness. Table 1 shows the categories of indecent language used on radio by ranking from highest to lowest.

Table 1: Indecent Language by Ranks

\begin{tabular}{|l|l|l|l|}
\hline No. & Type & Number of Incidents & Percentage \\
\hline 1 & Insulting and offensive comments & 91 & $36 \%$ \\
\hline 2 & Unsubstantiated allegations & 87 & $34 \%$ \\
\hline 3 & Provocative comments & 41 & $16 \%$ \\
\hline 4 & Remarks endorsing violence & 24 & $9 \%$ \\
\hline 5 & Remarks inciting violence & 7 & $3 \%$ \\
\hline 6 & Expressions or comments promoting divisiveness & 4 & $2 \%$ \\
\hline
\end{tabular}


Out of the 254 cases of indecent language recorded for the given period, insulting and offensive comments ranked the highest $(36 \%)$, followed by unsubstantiated allegations with $34 \%$, while expressions or comments promoting divisiveness ranked the lowest form of indecent language used on Ghanaian radio (2\%). Details about the categories of indecent language identified on Ghanaian radio are provided below. In the accompanying examples, names of persons at whom the indecent expressions were targeted were substituted with placeholder names such as "so and so" in order not to perpetuate the indecency towards them. Names of towns and regions were likewise replaced by placeholder names. Similarly, names of speakers have been omitted for the sake of confidentiality.

\section{Insulting and Offensive Comments}

This comprised disrespectful remarks targeted at a person. These remarks were usually aimed at hurting the target. Impoliteness strategies used to achieve these speech acts were bald on record impoliteness and negative impoliteness. Examples are as follows:

\section{Example 1: 16/05/2016 Akan (Twi)}

a-koa wei nso de $\varepsilon$, na a-dwene n-ye; Asem $\varepsilon$ side $\varepsilon$ ase a-kwaadaa bi.

SG-slave DEF too DET, and SG-mind NEG-good; Asem $\varepsilon$ siDET like SG-child INDF

Trans lation: This guy is a nutjob; So and so is like a child.

Every culture finds children adorable. However, regardless of their adorable nature, it is a fact that children are also naïve and immature. They are not able to take care of themselves; they cannot be left on their own but need the constant supervision of adults. Children lack maturity and the requisite wisdom needed to guide them in decision-making. Hence, in comparing So and so to a child, the speaker is insinuating that $\mathrm{s} /$ he is immature and unable to think for himself/herself. Then again, the speaker alleges that So and so is a nutjob. So beyond his/her immaturity and inability to think for himself/herself, So and so is said to be lacking sanity, which sends the signal that $\mathrm{s} /$ he is even not fit to make sound decisions and judgments and therefore should be ignored. This speech act is definitely performed with the intent of hurting the target. This is a direct bald on record statement, as well as negative impoliteness strategy.

\section{Example 2: 15/06/2016 Akan (Twi)}

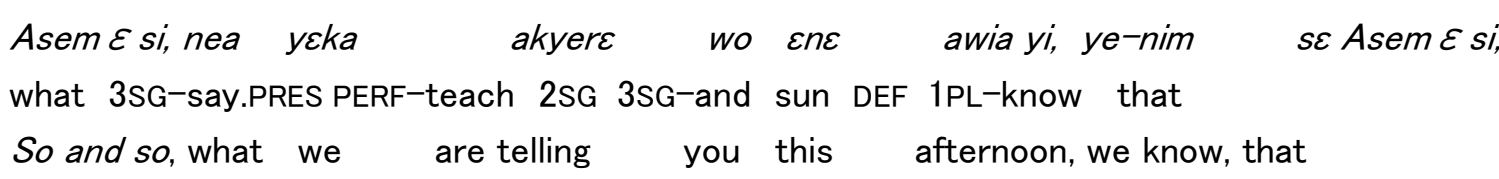

sebisebi, wose a-pr. Bra na $y \varepsilon-m m a$ wo toothbrush ne toothpaste excuse, 2SG-teeth PERF-rot. come.PRES and 1PL-give 2SG toothbrush and toothpaste excuse me to say, your teeth are rotten. Come and let's give you toothbrush and toothpaste

na ko twitwi, na yen-san mawo sapo ne samina na Jho-nam

and go.PRES brush, and 1PL-return give.PRES sponge and soap and SG.self-meat so you go brush your teeth and then we will also give you sponge so that you wash off kan $\varepsilon^{-w}$, wo ho a wo ko public a babia wo betena stink 3SG-be.PRES 2SG self CNJ 2SG go.PRES public SUB wherever 2SG FUT-sit your body odour, when appear in public, where ever you sit,

biaa no obia n-tumi ntena homom, $y \varepsilon-b \varepsilon-m a$ wo sapo ne any DEF any person NEG-can NEG-sit there, 1PL-FUT-give 2SG sponge and no one can sit there.

We will give you sponge

na samina woadware ho fi wo badwam.

and soap 2SG-PERF-bath 2SG self dirt in public

and soap to clean your dirty self in public. 
In this example, a personal attack is launched on the physical appearance of the subject of discussion. A picture is painted of someone who has no regard for personal hygiene and therefore has rotten teeth, and body odour. The impression is given that So and so neither baths nor brushes his/her teeth. The speaker goes on to say that $\mathrm{s} / \mathrm{he}$ and others would provide him/her with sponge, soap, toothpaste and toothbrush. This gives the impression that So and so is either so poor that $\mathrm{s} /$ he cannot afford to buy these basic necessities or is so uncouth that $s /$ he couldn' $t$ care less about acquiring them. It also shows that $s /$ he is not sensible enough to know that $\mathrm{s} /$ he has to keep good personal hygiene. Beyond this, the impression is created that So and so is a person who people avoid because of his/her unhygienic state. Clearly, this is such an unsavoury way to describe anybody, and this speech act is definitely aimed at hurting the target. The strategy used here is bald on record impoliteness, as well as negative impoliteness as the target gets ridiculed.

\section{Unsubstantiated Allegations}

Unsubstantiated allegations comprised claims made without factual or evidential backing. Unsubstantiated allegations had the capacity to damage the reputation of the targets. Their mere utterance incited the targets to react. The impoliteness strategies employed to make these unsubstantiated allegations were bald on record impoliteness, where the utterances were direct, clear, unambiguous, and negative impoliteness where the target's negative face wants were destroyed. Examples of unsubstantiated allegations identified include the following:

\section{Example 3: 05/05/2016 Akan (Fanti)}

\begin{tabular}{|c|c|c|c|c|c|}
\hline E-wia & sika & $\varepsilon-d e$ & $a-k$. & & doctor (doctorate degree). \\
\hline 3sG-steal & sika & 3SG-do.PRES & PERF-buy & doctor. & \\
\hline You stole & money & to & buy yourself & a doct & corate degree \\
\hline
\end{tabular}

$\mathrm{Na} \quad \varepsilon-k \supset$-gye doctor nsoa balcony $\supset$ gye doctor in charge
and 3SG-go-take doctor too balcony 3SG-take doctor in charge
of siphoning money to Anytown, doctor in charge of corruption, doctor in

charge of embezzling Ghana money, doctor in charge of w $\supset$-wia Ghana charge of embezzling Ghana money, doctor in charge of 3PL-steal Ghana charge of embezzling Ghana's money

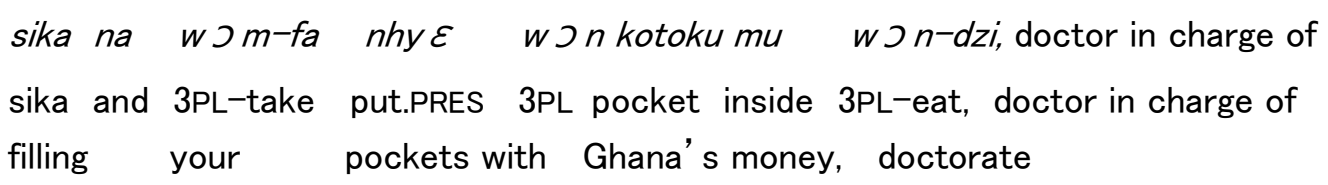

a-kohwis $\varepsilon m$.

SG-lie

in lies

The speaker here makes a number of allegations. Firstly, s/he alleges that the "accused" is a thief. In every culture, thieves are seen as deviants and are frowned upon as they deprive people of their possessions. Thieves are treated like a canker in the Ghanaian society. People are known to hide their valuables from those they perceive to be thieves. Also, in the traditional African setting, families would typically object to their ward marrying someone who is known to be a thief. Therefore, nobody would want to be associated with such behaviour. However, this speaker calls the "accused" a thief without any proof, thereby tarnishing his/her image and reputation. Beyond that, the speaker also alleges that the person's doctorate degree was not earned but rather bought. This allegation presupposes that the "accused" is corrupt, dishonest, dishonourable and unintelligent as $\mathrm{s} / \mathrm{he}$ is unable to earn a degree through studies. 
Unfortunately, this allegation goes beyond the "accused" to the institution from which s/he acquired his/her doctorate degree, as by inference one can say that the institution sells degrees and is therefore corrupt and dishonourable too. The speaker goes on to make other allegations by indicating that the person's doctorate degree is even in 'siphoning money' which implies that $\mathrm{s} /$ he is so perverse that $\mathrm{s} /$ he has learned the "art" of thievery. Again, it is an indictment on the institution the "accused" attended because it means it is not a credible institution. To make matters worse, the accuser goes ahead to say that the doctorate degree is "doctorate in lies." So the accused is not only a thief but also a liar who has specifically acquired academic knowledge on how to steal and lie.

\section{Example 4: 13/06/2016 Akan (Twi)}

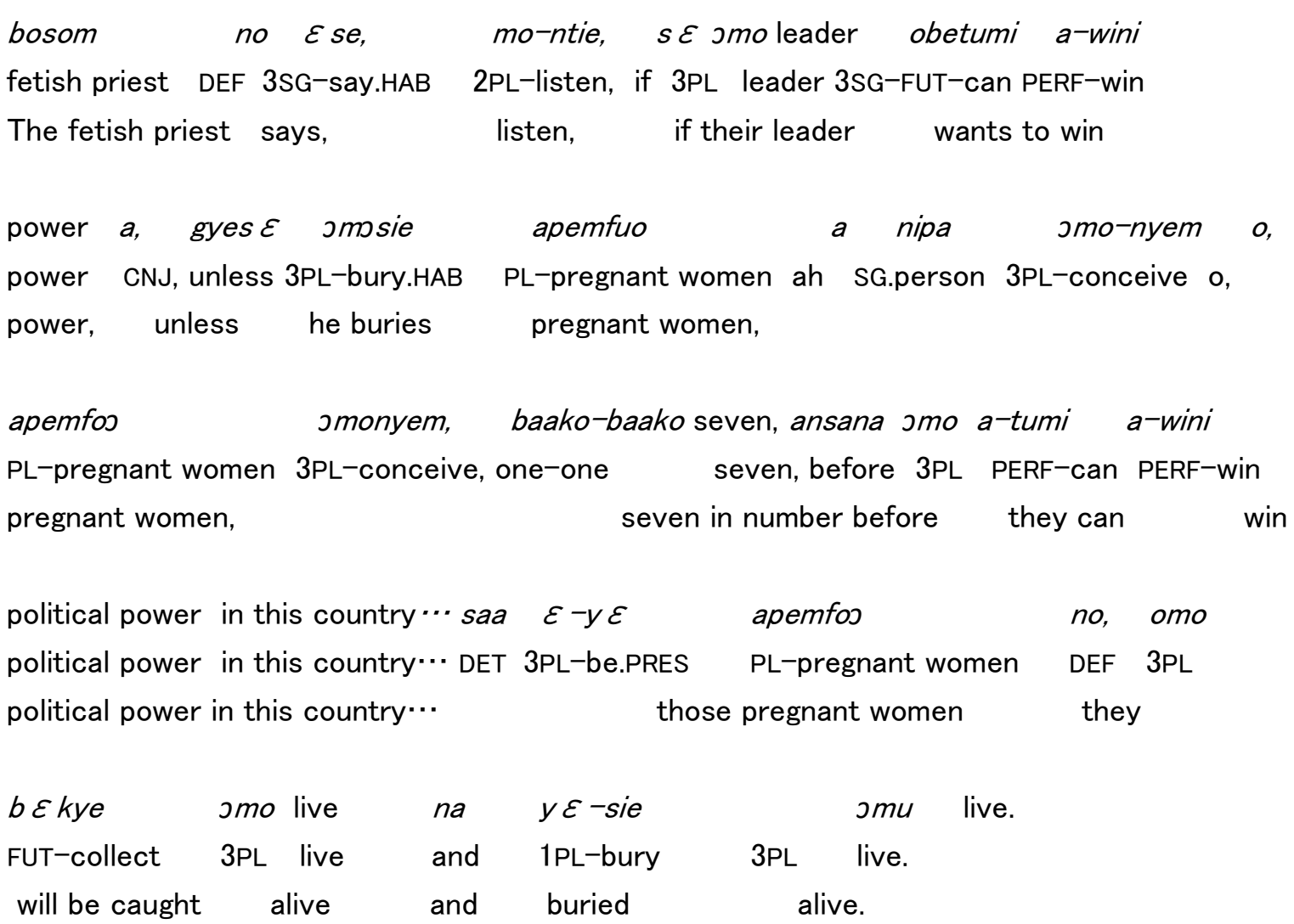

Fetish priests have been part of African traditional society and belief systems since time immemorial. However, in modern day Africa, fetish priests are generally viewed negatively. As a result, people who consult fetish priests usually do so secretly so that they cannot be sighted. Alleging, then, that someone has gone to see a fetish priest is quite horrendous. Even more horrendous are the allegations that follow; that the fetish priest would bury seven pregnant women alive for the person under discussion to win political power. Definitely, as a speech act, this allegation only seeks to project the person under discussion as a very wicked individual who yearns for political power desperately and therefore would not even mind exchanging several human lives for it. It also seeks to show the supposed depravity of the person under discussion, thereby making the listener appalled at this person.

\section{Provocative Comments}

Provocative comments have a very high tendency to infuriate others. Impoliteness strategies adopted to make provocative comments are bald on record impoliteness, and negative impoliteness. Examples are:

\section{Example 5: 24/06/2016 Akan (Twi)}

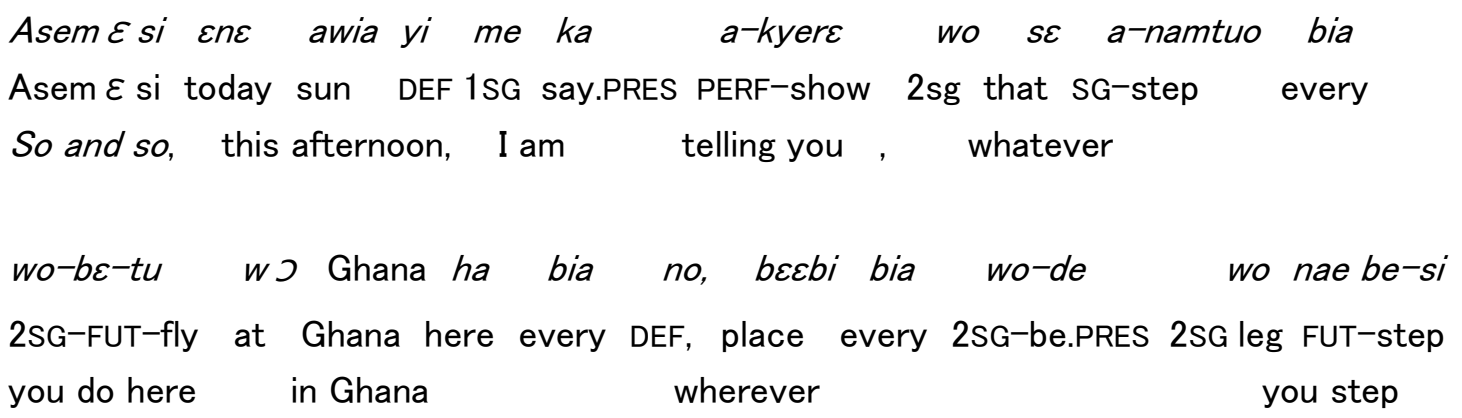




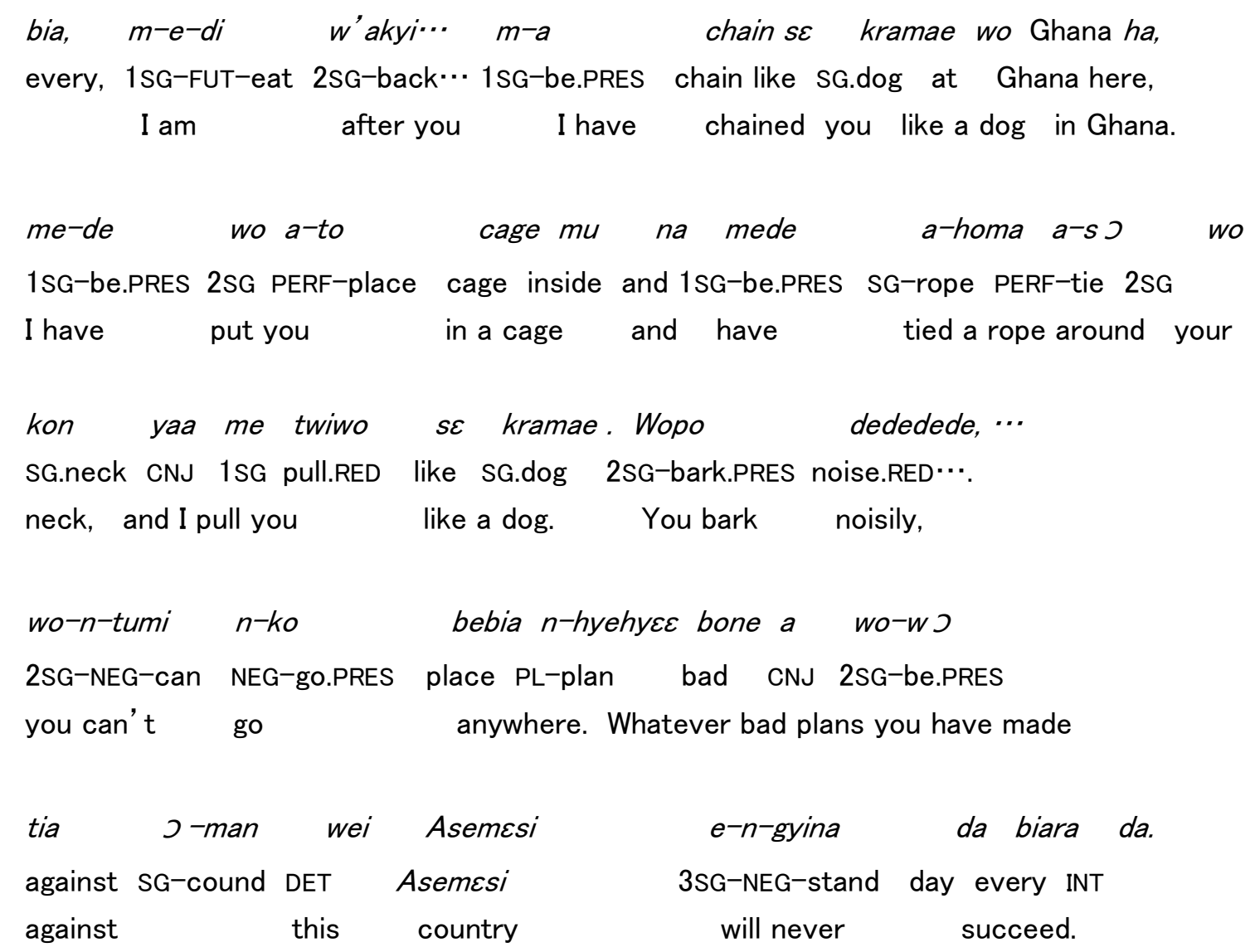

In this example, we see a very powerful but negative imagery as the speaker compares So and so to a dog. The dog, they say, is man's best friend. In Ghana, the dog is also believed to be a spirit guide. Hence, one clan has a dog as its totem. However, there is also a tradition that sees dogs as filthy animals that roam about for scraps and mess up wherever they go. It is therefore demeaning to be compared to a dog in Ghana. However, this is just what the speaker does here. S/he goes on to say s/he has chained So and so and tied a rope around his/her neck, thereby showing that $s /$ he is So and so's keeper and has absolute control over $\mathrm{him} / \mathrm{her}$. This also means that $\mathrm{s} / \mathrm{he}$ has put So and so under incarceration. S/he continues that So and so barks noisily which means that $S o$ and so is a loud-mouthed and uncouth person.

\section{Example 6: 10/06/2016 Akan (Twi)}

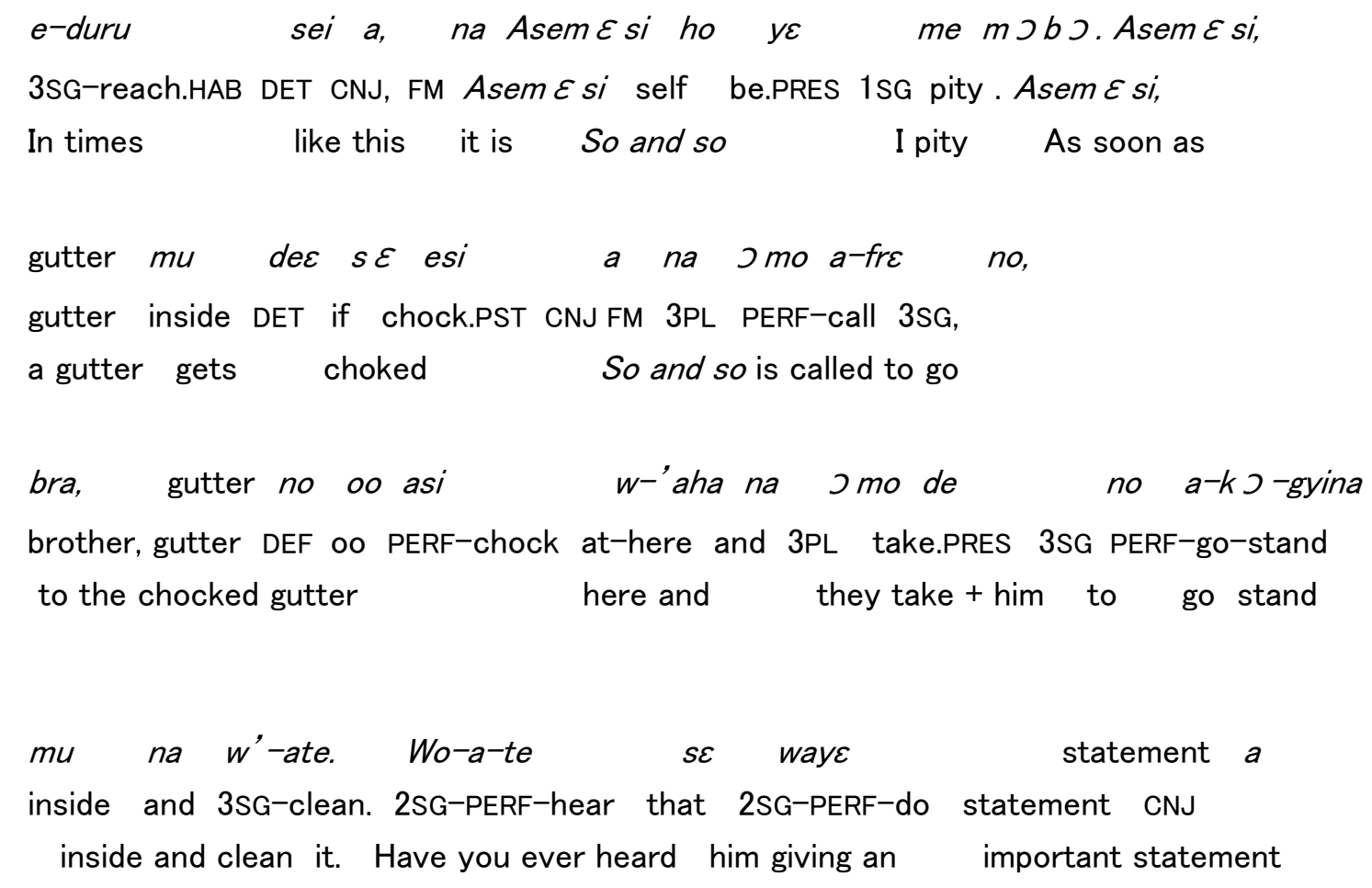

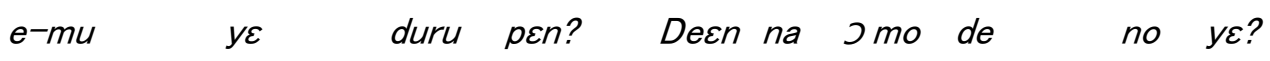

3SG-inside be.PRES heavy before? what FM 3SG be.PRES 3SG do.PRES?

executing a major task? what use is he to them? 


$$
\begin{aligned}
& \text { wo dee kyere } m \varepsilon . " \\
& \text { 2SG DET teach.PRES 1SG. } \\
& \text { You tell me }
\end{aligned}
$$

In this example, So and so is described in a denigrating manner. The kind of commentary given about him/her projects someone who is not respected or regarded. It is projected that $\mathrm{s} / \mathrm{he}$ is irrelevant and is only called upon to attend to unimportant, disrespectable, and trivial tasks. The commentary also gives the impression that $\mathrm{s} /$ he is someone who has no freedom but is at the beck and call of other people.

\section{Remarks Endorsing Violence}

Remarks endorsing violence were aimed at taking a stance for violence. They were expressions which approved violence. They usually took the form of bald on record impoliteness as they were direct, clear, and unambiguous. Examples included:

\section{Example 7: 09/05/2016 Akan (Twi)}

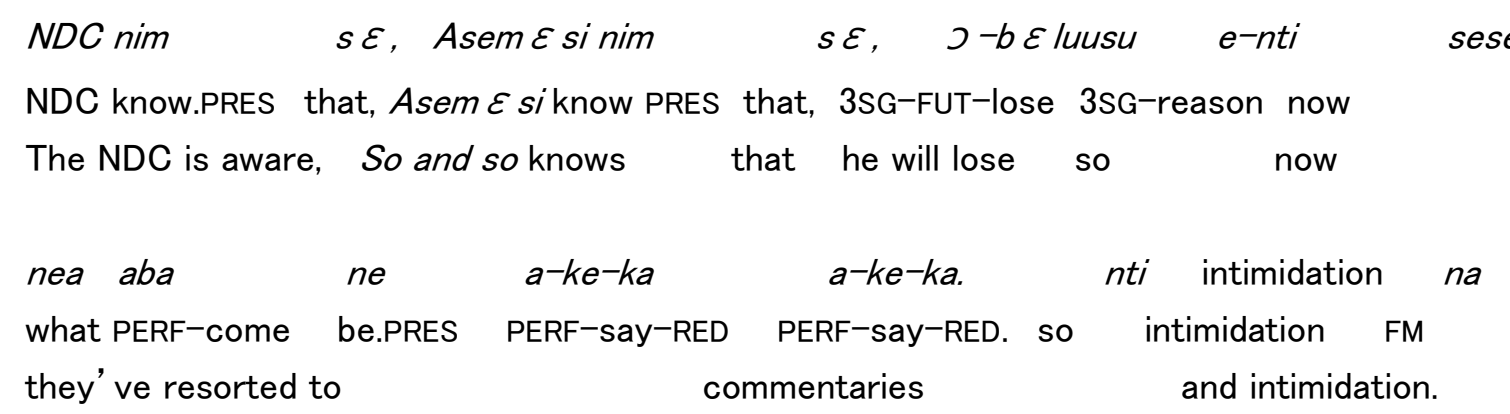

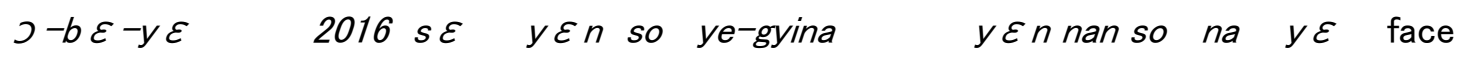

3SG-FUT-do.PRES 2016 that 1PL too 1PL-stand.PRES 1PL leg top and 1PL face

in 2016. We should also be bold enough to face

wona, Jmose enona Jbentenkae a Jmo n-tease

3PL SUB, 3PL say.PRES 3PL FM 3SG someone say.PST CNJ 3PL NEG-understand them, as So and so said and was misunderstood.
because me me-n-n-kJ-gyina
polling station na wo m-ma
because 1SG 1SG-NEG-IMP-go.PRES-stand-PRES polling station and 2SG NEG-com
Because I will not forgive you at the polling station if

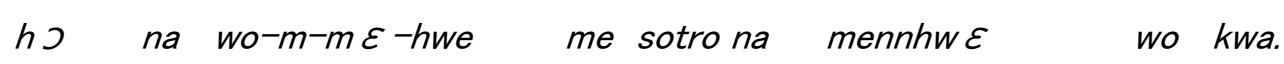

there and 2SG-NEG-FUT-beat 1SG slap and 1SG-N-IMP-look 2SG non-entity you slap me. The manner in which

all die be die. Mese $\quad m-e-y \varepsilon$ polling agent anaas $\varepsilon$ m-a-ba all die be.PRES die. 1SG.say.PRES 1SG-FUT-do polling agent or 1SG-PERF-come one dies does not matter. If I am a polling agent or

as a chairman, for $X Y Z$ Region first vice chairman, $m-e-k J \quad$ rounds as a chairman, for $X Y Z$ Region first vice chairman, 1SG-FUT-go round.PL a first vice chairman for $X Y Z$ Region If I' $\mathrm{m}$ going on rounds

$\begin{array}{lccccc}\text { na } & \text { me } & \text { kita } & m e & \text { accreditation na } m-a-b a & n a \\ \text { and } & \text { 1SG } & \text { hold.PRES } & \text { 1SG.POSS } & \text { accreditation and 1SG-PERF.come and that } \\ \text { with } & & \text { my } & & \text { accreditation }\end{array}$




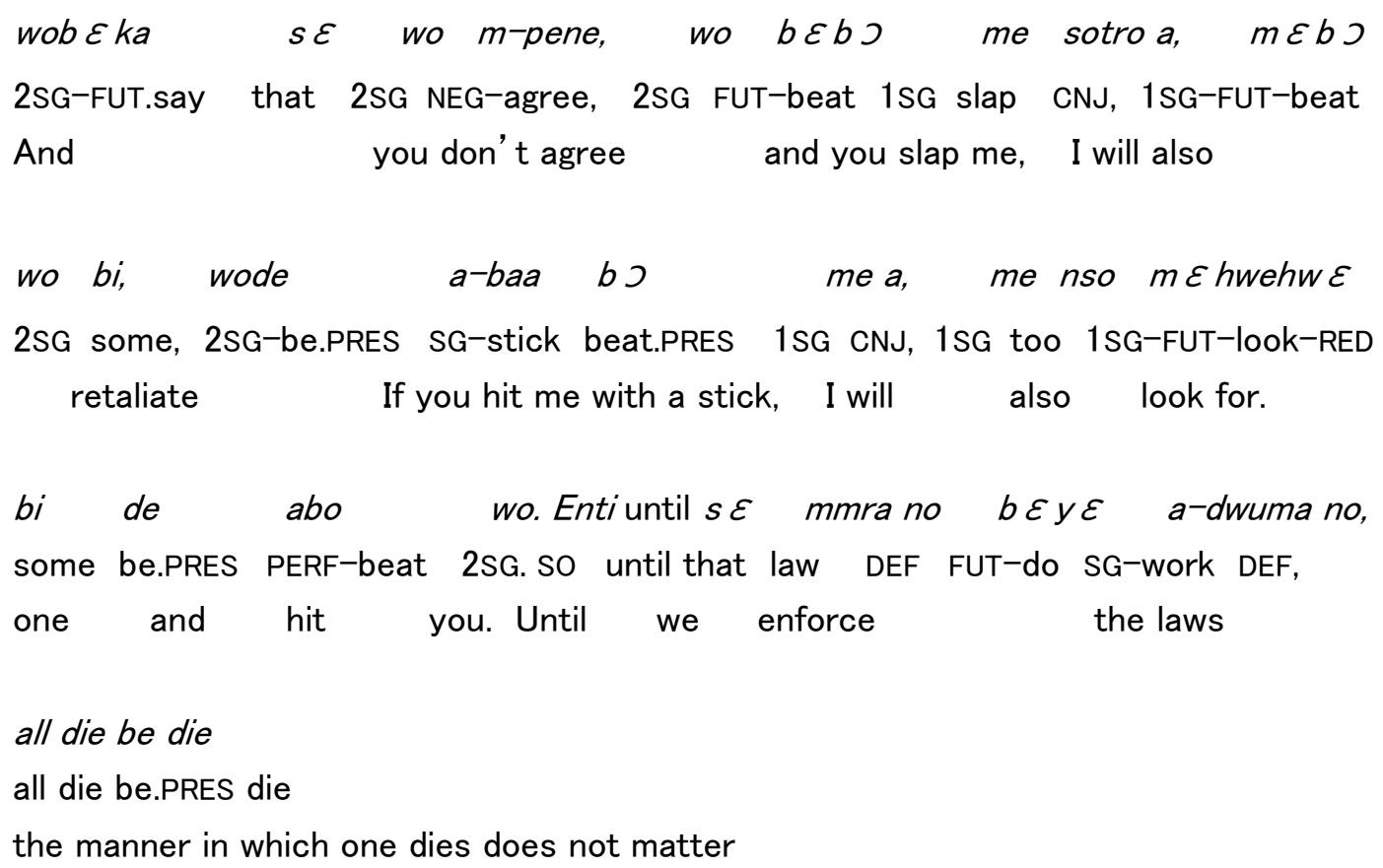

In this example, we encounter a speaker advocating for the law of retaliation. Not only is $\mathrm{s} / \mathrm{he}$ doing that but also $\mathrm{s} /$ he has a preconceived notion that his/her political opponents would be violent. $\mathrm{S} / \mathrm{he}$ is therefore ready to retaliate using any means necessary, even if it means death; for "the manner in which one dies does not matter."

\section{Remarks Inciting Violence}

Unlike those remarks that endorse violence, a section of the data produced instances of remarks that have the tendency to trigger violence in the country. In other words, these are inflammatory remarks which have the capacity to arouse and fuel violence. The impoliteness strategy used can be identified as negative impoliteness. Examples are:

\section{Example 8: 09/05/2016 Akan (Twi)}

I believe $d \varepsilon$, party biara $m-m \supset$ ne ho ban. The party vigilantes no,

I believe that, party any IMP-play 3SG self fence. The party vigilantes DEF,

I believe that all parties should protect themselves. The Party vigilantes

$$
\varepsilon-w \supset \quad d \varepsilon \quad y \varepsilon-h y \varepsilon \quad m u \quad k e n a . N P P \quad y \varepsilon-m-p \varepsilon \quad \text { menyin-fo, }
$$

3SG-be.PRES that 1PL-command inside well. NPP 1PL-NEG-like man-PL

Should be encouraged. NPP should look for strong party men

$$
y \varepsilon-m-p \varepsilon \quad m e s i a f o \quad a \text { won ani } y \varepsilon \text { den. Afei nso ntokwa hwehwam na }
$$

1PL-NEG-like woman-PL REL 3SG eye be.PRES hard now too fight interesting FM and women. Now we should all protect ourselves because of the interesting fight
$N D C \varepsilon-d e$
ba
no, $\quad y \varepsilon m b J$
$y \varepsilon n$ ho ban. NPP-ni

NDC 3SG-be.PRES come.PRES 3SG, 1PL-IMP-play 1PL self fence. NPP-person

NDC is coming up with. Because we don' $t$ govern a nation

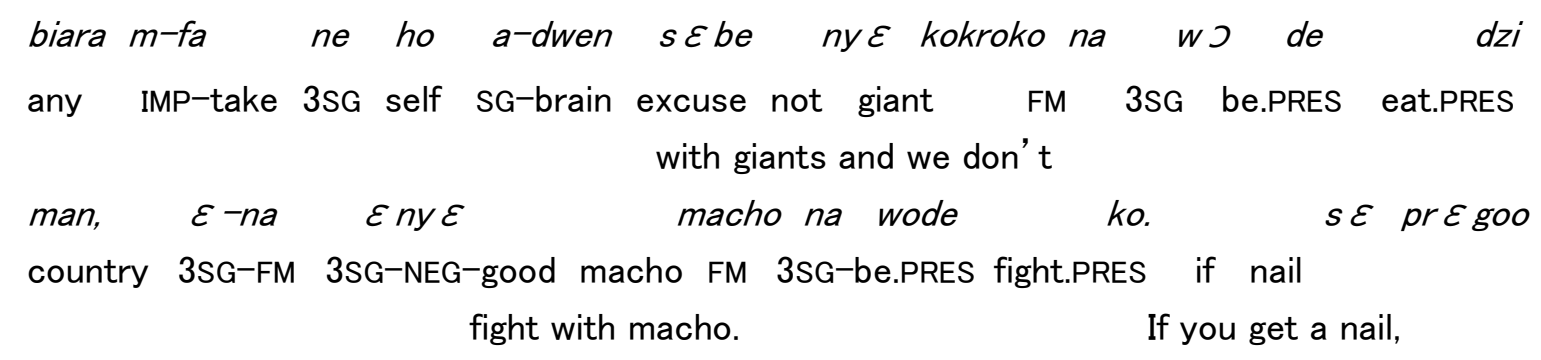


Take.PRES put.PRES 2SG pocket inside. All die be.pres die. 3SG-come.PRES

Keep it in your pockets. The manner in which one dies does not matter

na $s \varepsilon \supset-b \varepsilon-b o$ wo $a$, fa wJ no ma om-pira."

And if 3SG-FUT-beat 2SG CNJ, take stab.PRES 3SG so 3SG-hurt

If anyone comes to beat you, stab him/her with it.

Political party vigilantism has been a bane of Ghana's democracy. Political parties organise a group of ordinary citizens made up of chiefly muscular people to protect members of the party, and to "oversee" elections to prevent rigging. These party vigilantes are mostly violent in nature and will do anything to champion the cause of their parties. This speaker promotes vigilantism and suggests that muscular people should be selected and armed to fight political opponents. S/he even goes beyond and advocates for the stabbing of political opponents. The speaker gives the indication that vigilantes should be ready to die for the cause of the party, regardless of how they die. Another example of such inflammatory statements is presented below:

\section{Example 9: 19/07/2016 Akan (Twi)}

NDC-fo $\supset$ astaate $\supset$ mo ade no biom, titrew ne ABC Region,

NDC-people PERF.start 3SG thing DEF again, especially be.PRES ABC Region, NDC people have started doing their things again especially in $\quad A B C$ Region

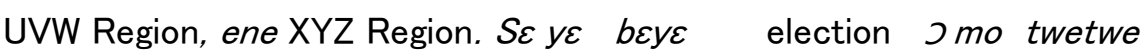

UVW Region, and XYZ Region. If 1PL FUT-do election 3SG pull.RED

UVW Region and XYZ Region. When there is going to be an election they take

mayafi ne adeade. Me-sere me dec se police ben, wo-fa scarf and thing.RED. 1SG-beg.PROG 1SGDET if police close.PRES 3SG-take.PRES scarf and others to mask themselves. I am begging, if the police are close hand them

no kJ butmo hwe paa no na sepolicefo $\supset$ mben mo na mo

3SG go.PRES but 3PL look.PRES INT 3SG and if police.PL NEG-close 3PL and 3PL over to the police but if you check and the police are not close by

\begin{tabular}{|c|c|c|c|c|}
\hline$b \varepsilon b o$ & no & $m o-m-b o$ & 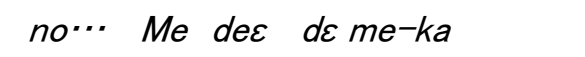 & no \\
\hline $\begin{array}{l}\text { FUT-beat } \\
\text { you }\end{array}$ & $\begin{array}{l}\text { 3SG CNJ } \\
\text { should }\end{array}$ & $\begin{array}{l}\text { 3PL-IMP-beat } \\
\text { beat them... }\end{array}$ & $\begin{array}{c}\text { 3SG } \cdots \text { 1SG DET what 1SG-say.PRES } \\
\text { what I have said }\end{array}$ & $\begin{array}{l}\text { 3SG like } \\
\text { is }\end{array}$ \\
\hline
\end{tabular}

nokware ne se wo ye kayayooni na obi ba na J-se

truth be.PRES if 2SG be.PRES head porter and 3SG come.PRES and 3SG-say.PRES

the truth If you are a head porter and someone

comes

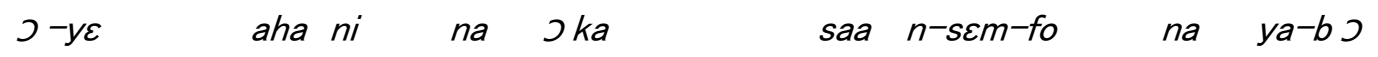

3SG-be.PRES THIS PLACE and 3SG.say.PRES DET PL-word-bad and 1PL-contact.PST that he is from this place and speaks nonsense then the person no paa mo-m-fa pan $m-b o$ no I'm telling you $m-\varepsilon-k J$

3SG laborer 3PL-IMP-take.PRES basin IMP-hit 3SG I'm telling you 1SG-FUT-go 


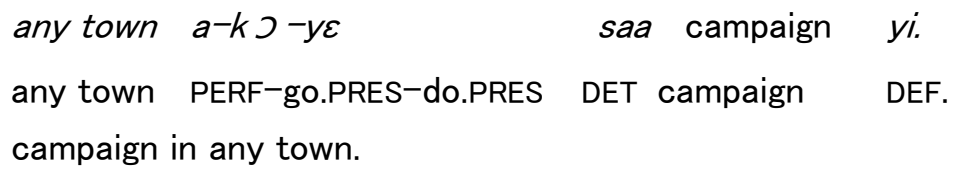

In this example, the speaker is seen brazenly advocating for people to take the law into their own hands and beat up members of the opposition political party. $\mathrm{S} /$ he also instructs head porters to use their basins (which they use to carry goods) to hit people. S/he does not end there but indicates that this is a campaign $\mathrm{s} /$ he will spend time, money, and energy, to travel to other towns/cities to wage.

\section{Expressions or Comments Promoting Divisiveness}

These were comments which had the capacity to engender disunity or hostility between different groups of people (ethnic groups, political groups, religious groups, etc.) in the country. They were usually contemptuous and could be considered as negative impoliteness. Examples of such comments were:

\section{Example 10: 03/05/2016 Dabgani}

Man ni nyeli shem yaa ni nye ka Muslim yina ti galindi lidi nindima la lahazibu. Ti yarimi yaa ti muslim nima disimdi ni nirbi yina ntiti jilima kaban ni ti gba be gina ni.kul yim Ghana din yela ni ka chan Nigeria tiyuli,a tehi ni Nigeria so ni tooi nine eh NDC ni nin shem maa,ka aku pee Christians nirba ayi ni a vice mini president kabe nye Christians a tehi ni Nigeria din tooi nin,amin chelya kati nirbi bi tila Muslim nim jilma dizugu kabi nindi shem maa.Nigeria yaa Gafaru laa beni kutooi bugsi. Ka NDC minister yina ti yeli ni muslem kutooi leb Ghana president, a tehi ni sheli polo din tooi nin.Ditumi ni Kaman yaa tam kam biyi yen tari tarili Ghana no kabi mi ni muslem nim gba beni.lugsheli polo bin tiri muslim nim jilma lala bin kutooi nin di zugu kan zan Nigeria taa example maa.

Trans lation: What I will say is that if I see a Muslim criticising So and so's statement, I get surprised. We are saying that Muslims must be accorded the needed respect and made part of the decision-making process. Just leave Ghana and go to Nigeria, do you think in Nigeria one can do what the eh...the NDC is doing? You just pick two Christians to be your vice and President? You think in Nigeria that can happen? I mean let's give our Muslims that respect. Gafaru in Nigeria you can't try that thing. Also, an NDC minister once said a Muslim cannot be president of Ghana. It has to be that when there is a cake to be distributed, Muslims would also have their fair share in this country. Places where they respect Muslims that's what happens that's why I gave you the Nigerian example.

Though a secular state, Christianity is Ghana's major religion, with over $70 \%$ of Ghanaians professing the Christian faith (Ghana Statistical Service, 2012). This is followed by the Islamic religion, and other religions. This speaker creates the impression that Muslims are left out of decision-making and therefore calls for a reversal of that trend. The speaker also finds it very unacceptable that a nation made up of Christians and Muslims should be governed by two Christians in the capacities of president and vice president. In short, the speaker calls for diversity. As genuine as it sounds, it promotes divisiveness since it implies that people should be looked at through the lenses of religion. 
The Extent to Which the Frequency and Type of Indecent Language Differ According to Gender

The analysis revealed that all categories of indecent language were mostly used by males as shown in Table 2 .

Table 2: Occurrence by Gender

\begin{tabular}{|l|l|l|l|}
\hline Category of indecent Language & Gender & Frequency & Percentage \\
\hline \multirow{2}{*}{ Unsubstantiated allegations } & & & \\
\hline \multirow{2}{*}{ Insulting and offensive comments } & Female & 4 & $5 \%$ \\
\cline { 2 - 4 } & Fale & 83 & $95 \%$ \\
\cline { 2 - 4 } & Male & 3 & $3 \%$ \\
\hline \multirow{2}{*}{ Remarks endorsing violence } & Female & 88 & $97 \%$ \\
\cline { 2 - 4 } & Male & 0 & $0 \%$ \\
\hline \multirow{2}{*}{$\begin{array}{l}\text { Expressions or comments promoting } \\
\text { divisiveness }\end{array}$} & Female & 24 & $100 \%$ \\
\cline { 2 - 4 } & Male & 0 & $0 \%$ \\
\hline Remarks inciting violence & Female & 4 & $100 \%$ \\
\cline { 2 - 4 } & Male & 7 & $0 \%$ \\
\hline Provocative comments & Female & 1 & $100 \%$ \\
\cline { 2 - 4 } & Male & 40 & $98 \%$ \\
\hline
\end{tabular}

Overall, the findings revealed that more males than females used indecent language on radio. The fact that women used less indecent language than men has a cultural dimension to it. In the African society, and for that matter the Ghanaian society, women are expected to be submissive in all circumstances. Therefore, society frowns upon women who openly use indecent language. This may explain why women were less likely to use indecent language than men.

\section{The Extent to Which the Frequency and Type of Indecent Language Differ According to Language (Local Versus English Language)}

Table 3: Occurrence of Indecent Language by Language

\begin{tabular}{|l|l|l|l|}
\hline Types of Indecent Language & Language & Frequency & Percentage \\
\hline \multirow{3}{*}{ Unsubstantiated allegations } & Local language & 79 & $91 \%$ \\
\cline { 2 - 4 } & English language & 8 & $9 \%$ \\
\hline \multirow{2}{*}{ Insulting and offensive comments } & Local language & 80 & $88 \%$ \\
\cline { 2 - 4 } & English language & 11 & $12 \%$ \\
\hline \multirow{2}{*}{$\begin{array}{l}\text { Expressions or comments promoting } \\
\text { divisiveness }\end{array}$} & Local language & 20 & $87 \%$ \\
\cline { 2 - 4 } & English language & 3 & $13 \%$ \\
\hline Remarks inciting violence & English language & 1 & $75 \%$ \\
\cline { 2 - 4 } & Local language & 7 & $25 \%$ \\
\cline { 2 - 4 } & English language & 0 & $100 \%$ \\
\hline Provocative comments & Local language & 31 & $0 \%$ \\
\cline { 2 - 4 } & English language & 10 & $76 \%$ \\
\hline
\end{tabular}

Overall, the study revealed that the majority of indecent language incidents on radio for the given period occurred in a local language. The analysis showed that all categories of indecent language occurred mostly in a local language as shown in Table 3. 


\section{The Extent to Which the Frequency and Type of Indecent Language Differ According to Type of Programme (News Versus Current Affairs)}

The analysis revealed that all categories of indecent language occurred primarily on current affairs shows (morning shows, late afternoon shows, newspaper reviews, and political talk shows).

Table 4: Occurrence of Indecent Language by Programme Category

\begin{tabular}{|l|l|l|l|}
\hline Category of Indecent Language & Type of Programme & Frequency & Percentage \\
\hline \multirow{2}{*}{ Unsubstantiated allegations } & News & 5 & $9 \%$ \\
\cline { 2 - 4 } & Current Affairs & 52 & $91 \%$ \\
\hline Insulting and offensive comments & News & 3 & $3 \%$ \\
\cline { 2 - 4 } & Current Affairs & 88 & $97 \%$ \\
\hline \multirow{2}{*}{ Remarks endorsing violence } & News & 0 & $0 \%$ \\
\cline { 2 - 4 } & Current Affairs & 24 & $100 \%$ \\
\hline \multirow{2}{*}{ Expressions or comments promoting } & News & 0 & $0 \%$ \\
\cline { 2 - 4 } Remarks inciting violence & Current Affairs & 4 & $100 \%$ \\
\hline Provocative comments & News & 0 & $0 \%$ \\
\cline { 2 - 4 } & Current Affairs & 7 & $100 \%$ \\
\hline
\end{tabular}

In general, the findings of the study showed that indecent language occurred more on current affairs programmes than on the news during the period under study.

\section{Discussion}

\section{Frequency and Kinds of Indecent Language on Ghanaian Radio}

The findings of this study are similar to many studies which have examined the phenomenon on broadcast media. Some of these studies include Sobieraj and Berry (2011); Somerville (2011); Marfo (2013); McCreary (2014); Ofcom (2016); Fordjour (2016); Ofori (2017); and Boateng (2018). Insulting and offensive comments, as indicated earlier, ranked highest among the 254 cases of indecent language usage on radio, and was consistent with the findings of MFWA $(2016 ; 2017)$ and Olúmúyìwá (2016). There is the possibility that unsubstantiated allegations, together with insulting and offensive comments ranked highest because people would want to destroy their opponent's (persons they disagree with) positive face wants by casting them in a negative light (Culpeper, 1996). Doing so has the likelihood of indirectly benefiting the one making the utterance, as his or her positive face wants will be reinforced. Unsubstantiated allegations, for instance, have the tendency to taint another person's reputation, therefore making him or her appear unsuitable for one thing or another, especially political office. Conversely, the accuser expects to gain by showing aversion to the condemned behaviour so as to become more preferable.

Expressions promoting divisiveness, remarks inciting violence, as well as remarks promoting violence may have ranked low because such utterances do not reinforce the speaker's positive face wants in any way. If anything, they rather affect the positive face wants of the speaker as $\mathrm{s} /$ he is seen as cantankerous, uncouth and therefore undesirable.

\section{Cultural Differences in the Use of Indecent Language in the Media}

On the whole, it was realised that the kinds of indecent language which occurred in the Ghanaian media were to an extent similar to those which occurred in the Nigerian media (Olúmúyìwá, 2016), as insults were found in both Ghanaian and Nigerian media. The findings of this study also showed that the types of indecent language used in the Ghanaian media differed from those used in the Western media, which were mostly related to sexual organs or sex (Sapolsky \& Kaye, 2009; Sapolsky, Shafer \& Kaye, 2010; Ofcom, 2016; Wildes, 2020). 
In the US media, for example, in contrast to insults as types of indecent language identified in Ghanaian media, Sapolsky and Kaye (2009) identified the following types of indecent language:

- Seven dirty words (shit, piss, fuck, cunt, cocksucker, motherfucker, and tits)

- Sexual words (words that describe sexual body parts; sexual behaviour, e.g. screw)

- Excretory words (words that made direct and literal references to human waste products and processes, e.g. poop, asshole)

- Mild-other words (e.g., hell, damn; Christ Jesus, and God are included if spoken in vain)

- Strong-other words (e.g., bastard, bitch, bullshit, and other words that evoke strong emotions and offense).

Most ethnic groups in Ghana (Akans, Ga, Ewes for example) consider sex organs as taboo and unmentionable (Yankah, 1995). Therefore, Ghanaians generally refrain from using such words in everyday discourse but rather resort to other types of indecent language.

In contrast to the above expressions in the US media, the study revealed that when Ghanaians decided to use indecent language in the media, they would rather cast an aspersion on another' s level of sanity. Again, the word 'thief' and its affiliates such as 'corrupt' are mostly used to describe others, which demonstrate moral bankruptcy. Adjectives such as 'fool and 'useless' are used quite often in the Ghanaian media. Also, consistent with the findings of Agyekum (2004) and Ofori (2017), animalization, that is comparing people to animals such as dogs, is also used commonly in the Ghanaian media to denigrate people. According to Ofori (2017), by doing so unpleasant features of the particular animal used are associated with the person who is being insulted. Also, in consonance with Ofori's (2017) findings, it was realised that infantilization of adults is another way in which indecency occurred in the Ghanaian media. Nevertheless, this study does not rule out the use of taboo words (sex related words) as insults in the Ghanaian media. As Fordjour (2016) reveals, some Ghanaians have been found to use sex related insults (lewd and profane expressions) on radio.

\section{Gender Differences in the Use of Indecent Language on Radio}

Contrary to Schippers' (2013) finding, which showed that there was no difference in the use of indecent language by males and females, this study found that males, more than females, tended to use indecent language on radio. This trend could be explained by the fact that more males tend to participate in radio discourse than females. A report by MFWA, for instance, revealed a decrease in women's involvement and participation in media discourse (MFWA, 2014). Traditionally, females are not supposed to be too opinionated, as such women are often stigmatised as cantankerous and unworthy of men's association. In extreme circumstances, such females are branded as quarrelsome, whores and/or witches. While societal advancement has caused a change in this situation, there are remnant effects on most women in Ghana, who would rather lead quiet/private lives than be in the public. Since more males engage in media discourse, more indecent language is bound to come from them. Besides, the few women who participate in such discussions try to be more decorous to avoid negative tags. Another dimension that explains the infrequent use of indecent language by women is that, in the African societies, it is a taboo for a woman to openly insult or use indecent words. This situation suggests that they have no right to challenge men and must not use vulgar language in their utterances, whether against their fellow women or men. Any woman who uses such unwholesome language in public is considered uncultured, undignified and discourteous. In most situations, such women are regarded as a social misfit and for that matter, their company is shunned by the society. In other respects, women of that nature are even considered unsuitable for marriage. This illuminates the high value society attaches to women who refrain from such unwholesome behaviour, hence the proverb: "Jbea sansani na shoro ne ntama hata no wo abJnten" [An undignified woman is the one who washes her dirty cloth in public]. Therefore, despite the societal advancement which may have caused a change in the cultural roles of women, this is one aspect of the culture of Ghanaians that has remained unchanged. Therefore, it is still a taboo for women to exhibit that kind of behaviour, hence any women who wishes to be respected in the society would refrain from such act. Interestingly, it is not very strange for men to engage in such activities. This may explain why women were not found to be using such indecent language. 


\section{Language Differences in the Use of Indecent Language on Radio}

This study showed that indecent language occurred mostly in a local language, thereby corroborating the literature (Fordjour, 2016; MFWA, 2017; Ismail and Deane, 2008; Somerville, 2011). Possible reasons for this could include the fact that local languages dominate the Ghanaian airwaves, and also radio scales the barriers of illiteracy. Currently, there are considerably more local language speaking radio stations than Englishspeaking radio stations in Ghana. Therefore, much of the discourse on radio occurs in local languages in which people feel more comfortable expressing themselves than in English, Ghana's official language. In some cases, people call into some English -speaking radio programmes and express the desire to contribute in a local language. Often, such people are allowed to contribute in a local language for a journalist to translate into English. The fact that English language is Ghana's official language subtly calls for circumspection in its usage, thereby requiring users to be more formal and therefore less indecent.

\section{Programme Differences in the Use of Indecent Language on Radio}

The study revealed that indecent language on Ghanaian radio stations occurred mostly on current affairs shows such as morning shows, late afternoon shows, newspaper reviews and political talk shows. This could be explained by the fact that news is primarily about informing listeners. This makes little room for in-depth discussions of issues raised, as compared to current affairs programmes. More importantly, most current affairs programmes in Ghana are political in nature, and during such shows, political opponents are pitted against each other to argue passionately about issues. In the course of heated arguments, indecent languages are usually traded as a result. This rubs off on listeners who toe the same line when making contributions to such programmes. This proves that the media are culpable in perpetrating and perpetuating verbal indecency, and thus gives further support to findings of earlier studies (Boateng, 2018; Ofori, 2017,2018; Asamoah, YeboahAssiamah and Osei-Kojo, 2014; Marfo, 2013).

\section{Impoliteness Strategies in the Use of Indecent Language on Radio}

The findings of this study revealed that two (bald on record impoliteness and negative impoliteness) out of the five impoliteness strategies identified by Culpeper (1996) were mostly adopted during indecent language usage on Ghanaian radio stations. Unlike the other three impoliteness strategies (positive impoliteness, withhold impoliteness, sarcasm or mock impoliteness), these are the strategies that do not resort to the use of filters or some level of discretion to make the impoliteness less harsh. This goes to show that when it comes to the usage of indecent language on Ghanaian radio stations, Ghanaians do not want to be neither coy about it nor circumspect. Also, Ghanaians do not resort to filters but rather go straight to the point. This could be explained by the fact that the time allotted to radio contributors or callers is limited, which therefore requires that patrons make the most out of it.

\section{Implications and Conclusion}

This study has shed light on the use of indecent language on Ghanaian radio stations by exploring the frequency and kinds of indecent language used on selected radio stations in Ghana over a nine-month duration. By doing so the study has proven the need for some measures to be put in place to curtail indecent language use, especially in political discourse where a lot of verbal indecency happens. Therefore, the MFWA's strategy of naming and shaming perpetrators and perpetuators of verbal indecency in the media is commendable. However, this must be complemented by stringent measures, such as the one proposed by Asamoah, Yeboah-Assiamah and Osei-Kojo (2014) for political parties to sanction members who use indecent language in political discourse. Beyond that, the media have a role to play in curtailing this practice as they have been found to be culpable (Boateng, 2018; Ofori, 2018). Thus, it will be useful for the media to adopt Marfo's (2013) proposed strategy of blacklisting people who use the media as a channel to verbally assault others. Doing that will forestall violence and prevent what happened in Kenya and Rwanda (Ismail and Deane, 2008; Somerville, 2011; Kellow and Steeves, 1998) from happening in Ghana. The fact that this study did not find the use of sexually-related words on Ghanaian radio suggests some cultural nuances, which implies that most Ghanaians still adhere to taboos. 
The findings of the study also highlighted the dynamics involved in the usage of indecent language on Ghanaian radio stations. People tended to use insulting and offensive comments more than the other categories of indecent language, usually in local languages on radio. Interestingly, though English words or phrases used hardly contained any insults or indecency, it buttresses the point made earlier that, as Ghana's official language, English was generally approached with circumspection. The fact that current affairs programmes contained more indecent language, and that more males than females used such language has implications for the choice of programmes and guests on such programmes.

The study also showed that users of indecent language on the Ghanaian airwaves were aware of what they were saying as they were able to construct meaningful utterances, which had specific purposes and the capacity to affect the target and audiences in one way or the other. Furthermore, the study revealed that Ghanaians who contributed to programmes on radio, during the period under study, preferred to use the harsher impoliteness strategies (bald on record impoliteness, and negative impoliteness) among the five impoliteness strategies identified by Culpeper (1996).

This study has implications for journalists who are in charge of current affairs radio programmes. Once it has been established that males are more likely to use indecent language than females, producers should encourage greater female participation. Radio hosts should be more alert to control the programme to prevent indecent language use. Since current affairs shows attract more indecency, hosts and producers should see the need to reconstruct such shows to curtail indecent language on radio. 


\section{References}

Agyekum, K. (2004). Invective language in contemporary Ghanaian politics. Journal of Language and Politics. 3(2). 345-375

Amoakohene, I. M. (2012). Political communication in Ghana's emerging democracy: newspaper coverage of two opposing political regimes in Ghana's Fourth Republic. Saarbrücken: LAP LAMBERT Academic Publishing.

Asamoah, K., Yeboah-Assiamah, E., \& Osei-Kojo, A. (2014). Demons of transitional democracies: Politics of insults and acrimony in Ghana. Journal of Social Science Studies, 1(1), 44-56.

Bainbridge, J. (2011). Tools 3: Textual analysis and media research. Media and Journalism: new approaches to theory and practice, 224-237.

Bauer, M. W., Bicquelet, A., \& Suerdem, A. K. (Eds.) (2014). Text analysis: An introductory manifesto. SAGE Benchmarks in Social Research Methods, 1, xxi-xlvii.

Boateng, A. (2018). Democracy and politics of insults in Ghana: the media factor. An unpublished thesis. Istanbul Commerce University.

Brown, P., Levinson, S. C., \& Levinson, S. C. (1987). Politeness: Some universals in language usage. Cambridge: Cambridge University Press.

Culpeper, J. (1996). Towards an anatomy of impoliteness. Journal of pragmatics, 25(3), 349-367.

Culpeper, J. (2005). Impoliteness and entertainment in the television quiz show: The Weakest Link. Journal of Politeness Research. Language, Behaviour, Culture, 1(1), 35-72.

Fordjour, E. A. (2016). Foul language in the Ghanaian electronic media: A case study of some selected radio stations in Kumasi, Ghana. International Conference on Management, Communication and Technology, 4(1), 26-32.

Ghana Statistical Service (2012). 2010 population and housing census: Summary report of final results. Accra: Sankofa Press Limited.

Gustafson, E. (2017). Swearing on television-gender, language, and power in The thick of it. Rask, 46, 97-119.

Ismail, J. A., \& Deane, J. (2008). The 2007 general election in Kenya and its aftermath: The role of local language media. The International Journal of Press/Politics, 13(3), 319-327.

Kaye, B. K., \& Sapolsky, B. S. (2009). Taboo or not taboo? That is the question: Offensive language on primetime broadcast and cable programming. Journal of broadcasting \& Electronic media, 53(1), 22-37.

Kellow, C. L., \& Steeves, H. L. (1998). The role of radio in the Rwandan genocide. Journal of communication, 48(3), 107-128.

Laary, D. I. (2016, April 24). MFWA Introduces Language Monitoring-Instrument to Check Abusive Speech. Retrieved from https://newsghana.com.gh/mfwa-introduces-language-monitoring-instrument-to-checkabusive-speech/)

Marfo, S. (2013). Thinking of peace, democracy and politics of insults in Ghana: The paradox of freedom and culture of violence. European Scientific Institute, 522-530.

McCreary, B. J. (2014). Five filthy words: Offensive language and primetime television programming. Theses and Dissertations (All). Indiana University of Pennsylvania.

McKee, A. (2001). A beginner's guide to textual analysis. Metro Magazine, (127), 138-149.

Media Foundation for West Africa (2014, July 15). Women's Participation in Media Discourse Dips Further: MFWA Report. Retrieved from https://www.mfwa.org/country-highlights/womens-participation-in-mediadiscourse-dips-further-mfwa-report/)

Media Foundation for West Africa (2016). Report on Indecent Language on Radio. Accra: Media Foundation for West Africa.

Media Foundation for West Africa. (2017). Watching the Watchdog. Indecent Campaign Language Use on Radio during Ghana's 2016 Elections. Accra: Media Foundation for West Africa. 
National Communications Authority (2020). List of Authorised VHF-FM Radio Stations in Ghana as at June, 2020. Accra: National Communication Authority.

Noelle-Neumann, E. (1974). The spiral of silence a theory of public opinion. Journal of communication, 24(2), 43-51.

Ofcom (2016). Attitude to potentially offensive language and gestures on TV and radio. London, UK: Ipsos MORI.

Ofori, E. A. (2018). Inter-party insults in political discourse in Ghana: A critical discourse analysis. African linguistics on the prairie, 21.

Ofori, E. A. (2017). The Use of Insults to Challenge Political Authority: A Critical Discourse Analysis. Language, Discourse \& Society, 5(1), 129-143.

Olúmúyìwá, T. (2016). The Linguistic Appraisal of Foul Language in Selected Yorùbá Video Films. Journal of Siberian Federal University. Humanities \& Social Sciences, 2 (9), 294-309.

Reporters without Borders. (2020). World Press Freedom Index 2020. Retrieved from https://rsf.org/ranking.

Republic of Ghana. (1992). 1992 Constitution of the Republic of Ghana. Republic of Ghana.

Ricke, L. D. (2012). Funny or Harmful? Derogatory Speech on Fox's Family Guy. Communication Studies, 63(2), 119-135.

Sapolsky, B. S., Shafer, D. M., Kaye, \& B. K. (2010). Rating offensive words in three television program contexts. Mass Communication and Society, 14(1), 45-70.

Sarpong, A. K. K. (2018, June 15). Indecent language use in public is anti-Ghanaian. Retrieved from https://www.ghanaweb.com/GhanaHomePage/features/Indecent-language-use-in-public-is-anti-Ghanaianculture-660473.

Schippers, A. F. (2013). Bad Language in Reality: A Study of Swear Words, Expletives and Gender in Reality Television. Doctoral dissertation, Thesis. University of Gothenburg.

Sobieraj, S., \& Berry, J. M. (2011). From incivility to outrage: Political discourse in blogs, talk radio, and cable news. Political Communication, 28(1), 19-41.

Somerville, K. (2011). Violence, hate speech and inflammatory broadcasting in Kenya: The problems of definition and identification. Ecquid Novi: African Journalism Studies, 32(1), 82-101.

Thompson, R. A., \& Anderson, J. A. (2018). Interactive programmes on private radio stations in Ghana: An avenue for impoliteness. Journal of African Media Studies, 10(1), 55-72.

Wildes, H. E. (2020). The Proliferation of Indecent and Profane Content on Modern Broadcast Television: A Qualitative and Quantitative Content Survey. (An unpublished thesis for M.S. in Television Management, Drexel University).

Wimmer, R. D., \& Dominick, J. R. (2011). Mass media research: An introduction. Boston, MA: Wadsworth Cengage Learning.

Yankah, K. (1995). Speaking for the chief: Okyeame and the politics of Akan royal oratory. Bloomington, IN: Indiana University Press. 